\title{
Deteksi Spam pada Twitter Menggunakan Algoritme Naïve Bayes
}

\section{Spam Detection on Twitter using Nä̈ve Bayes Algorithm}

\author{
ANDITA WAHYUNINGTYAS ${ }^{1 *}$, IMAS SUKAESIH SITANGGANG ${ }^{1}$, HUSNUL $^{2}$ \\ KHOTIMAH $^{1}$
}

\begin{abstract}
Abstrak
Di era berkembangnya penggunaan Internet, Twitter merupakan salah satu layanan jejaring sosial yang sering digunakan sebagai alat komunikasi yang saling menghubungkan antar pengguna. Selain itu Twitter juga dimanfaatkan sebagai media untuk promosi, kampanye politik, dan sarana protes. Twitter dihadapkan pada berbagai masalah seperti gangguan privasi pengguna dan spam pada Twitter. Dengan adanya masalah spam, perlu dilakukan klasifikasi untuk tweet spam dan bukan spam. Penelitian ini bertujuan untuk mendeteksi tweet spam dan bukan spam. Hal tersebut dapat dilakukan dengan klasifikasi, terdapat berbagai macam metode klasifikasi, salah satu metode dalam data mining untuk mengklasifikasikan spam dan bukan spam adalah Naïve Bayes. Naïve Bayes banyak digunakan karena kesederhanaan algoritme dan mudah untuk diimplementasikan. Penelitian ini mengumpulkan data spam dari Twitter dengan mengidentifikasi terlebih dahulu akun yang diduga sebagai spammer. Penelitian ini menggunakan $70 \%$ data latih dan 30\% data uji dengan metode klasifikasi Naïve Bayes. Data Twitter yang diperoleh merupakan data teks yang masih banyak mengandung kata-kata yang tidak baku, sehingga dibutuhkan tahap praproses, tahap yang dilakukan adalah tokenizing, filtering, normalisasi kata, stemming. Akurasi hasil klasifikasi tweet spam dan bukan spam adalah $95.57 \%$.
\end{abstract}

Kata Kunci: klasifikasi spam, Naïve Bayes, text mining, Twitter.

\begin{abstract}
In this era of the Internet, Twitter is one of the social networking services that is often used as a communication tool between users to connect with each other. Twitter is also used as a tool for promotions, political campaigns, and protests. Twitter faces with various problems such as interference with user privacy and spam messages. With the existence of spam problem, classification of spam and non-spam tweet needs to be done. This research aims to detect spam and non-spam tweet, which can be done by the classification task. One of the methods in data mining to classify spam and non-spam is Nä̈ve Bayes algorithm. Nä̈ve Bayes algorithm is widely used because of its simplicity and easy to implement. This research collects spam data from Twitter by identifying accounts that are suspected as spammers. The data are split to $70 \%$ for training data and $30 \%$ for test data. The data are text data that still contains many non-standard words, so a preprocessing stage is needed. The stage which is done are tokenizing, filtering, text normalization, and stemming. The accuracy of the classification of spam tweet and non-spam tweet is $95.57 \%$.
\end{abstract}

Keywords: Naïve Bayes, spam classification, text mining, Twitter.

\section{PENDAHULUAN}

Di era berkembangnya penggunaan Internet, penggunaan Internet memberikan dampak langsung terhadap penggunaan media sosial. Pada tahun 2013, pengguna Internet di Indonesia mencapai 63 juta orang, 95 persen di antaranya menggunakan Internet untuk mengakses media sosial seperti Facebook dan Twitter (Kemenkominfo 2013).

Twitter merupakan salah satu layanan jejaring sosial yang sering digunakan sebagai alat komunikasi. Selain itu, Twitter juga dimanfaatkan sebagai media untuk promosi, kampanye

\footnotetext{
${ }^{1}$ Andita Wahyuningtyas, Departemen Ilmu Komputer IPB, 0251-8625584;

*Penulis Korespondensi: Tel/Faks: 0251-8625584; Surel: andita.wahyuningtyas@yahoo.com
} 
politik ataupun sarana protes. Fitur-fitur pada Twitter yang dapat dimanfaatkan antara lain seperti tweet, mention, reply, retweet, hashtag, following dan follower, direct massage, dan search. Tweet merupakan kegiatan post dan posting yang dilakukan oleh pengguna Twitter, jika di dalam tweet terdapat @username hal tersebut disebut dengan mention,mention dapat terlihat oleh pengguna yang di-mention walaupun bukan sebagai follower dari pengirim. Dengan adanya fitur-fitur yang ada pada Twitter, penggunaan Twitter semakin berkembang, sehingga Twitter dihadapkan pada berbagai masalah seperti munculnya spam. Spam pada Twitter adalah konten yang dikirim oleh akun palsu yang dibuat oleh spammer atau akun yang username dan password-nya telah dicuri oleh spammer (McCord dan Chuah 2011).

Tweet terbatas hanya 140 karakter, keterbatasan tersebut memaksa pengguna Twitter untuk melakukan penyingkatan kata. Hal tersebut menyebabkan isi tweet mengandung banyak kata yang tidak baku. Hal tersebut menjadi tantangan untuk mengolah data tweet menjadi katakata yang baku. Untuk mengolah data tweet menjadi baku dibutuhkan beberapa tahapan praproses, yaitu, tokenisasi, normalisasi kata, filtering, dan stemming. Tokenisasi adalah proses pemotongan kata menjadi bagian-bagian kecil atau disebut token. Pada tokenisasi akan membuang karakter, seperti tanda baca dan angka. Normalisasi kata merupakan proses untuk penggantian kata yang tidak baku menjadi baku dan menghilangkan karakter berulang (Aziz 2013). Filtering adalah langkah untuk menghilangkan kata-kata yang jika dihilangkan, data tweet masih memiliki makna. Stemming adalah langkah untuk membuang imbuhan dan akhiran yang terdapat pada token.

Palupiningsih (2011) dan Makhtidi (2012) melakukan penelitian untuk menganalisis pola pada SMS untuk memprediksi apakah SMS berindikasi sebagai spam atau tidak. Dalam penelitian tersebut, Palupiningsih (2011) menggunakan algoritme Naïve Bayes dan berhasil mengklasifikasikan data spam dan bukan spam dengan akurasi sebesar $80.93 \%$. McCord dan Chuah (2011) melakukan penelitian untuk klasifikasi spam pada Twitter. Penelitian ini menggunakan fitur yang diambil dari masing-masing akun pengguna Twitter. Fitur yang digunakan adalah fitur user-based dan fitur content-based, yang termasuk kategori fitur userbased adalah hubungan pengguna seperti orang-orang yang pengguna ikuti dan orang-orang yang mengikuti pengguna atau prilaku pengguna seperti periode dan frekuensi pengguna mengirim tweet. Tahap awal penelitian ini adalah memilih secara acak 1000 akun Twitter dan memeberi label spam dan non spam secara manual, setiap akun dievaluasi 20, 50, 100 tweet terbaru yang di-posting oleh pengguna. Menggunakan algoritme Random Forest dengan presisi sebesar 95.7\% dan F-measure sebesar 95.7\%. Prototipe deteksi akun spam pada Twitter dibangun oleh Wang (2012). Studi ini menunjukkan bahwa bayesian classifier menunjukkan kinerja yang baik dibandingkan classifier lainnya dalam mendeteksi akun spam pada Twitter. Selain Bayesian classifier, algoritme machine learning yang lain yang banyak digunakan dalam deteksi spam pada Twitter adalah Random Forest (Chakraborty et al. 2016), Support Vector Machine dan Neural Network (Gupta et al. 2018).

Dari permasalahan berkembangnya kemunculan spam pada Twitter, maka dibutuhkan penelitian untuk menganalisis pola tweet untuk memprediksi apakah tweet terindikasi sebagai spam atau bukan spam. Dalam mengklasifikasikan terdapat berbagai macam algoritme, salah satunya adalah Naïve Bayes, Naïve Bayes banyak digunakan karena kesederhanaan algoritme dan mudah untuk diimplementasikan (Metsis et al. 2006). Oleh karena itu, penelitian ini dibutuhkan untuk membangun model klasifikasi untuk mendeteksi spam dan bukan spam dengan menggunakan algoritme Naïve Bayes.

Tujuan penelitian ini adalah 1) membangun model klasifikasi menggunakan algoritme Naïve Bayes dalam mendeteksi tweet ke dalam kelas spam dan bukan spam, dan 2) menganalisis isi tweet untuk mengidentifikasi kata yang digunakan sebagai spam. Penelitian ini diharapkan dapat membantu pengguna Twitter untuk mengklasifikasikan tweet spam dan bukan spam, sehingga tweet spam tidak muncul pada akun pengguna 


\section{METODE}

\section{Data Penelitian}

Data yang digunakan dalam penelitian ini adalah data tweet, yang didapat dari pengguna Twitter. Penelitian ini menggunakan 1000 data tweet yang diambil dari 25 akun spammer dan 25 akun bukan spammer yang telah ditentukan sebelumnya. Dari masing-masing akun diambil 20 tweet terbaru. Pengambilan data tweet diperoleh dalam rentang waktu Maret 2015-Agustus 2015. Data kedua yang dibutuhkan dalam penelitian adalah data stopwords yang digunakan untuk kebutuhan filtering, data stopwords dalam bahasa Indonesia yang digunakan dalam penelitian ini diperoleh dari (Tala 2003) yang berjumlah 759 kata. Data stopwords disimpan dalam format Comma Separated Value (CSV).

Data yang dibutuhkan selanjutnya adalah data kata dasar yang digunakan untuk kebutuhan stemming, Data kata dasar pada penelitian ini disimpan di dalam basis data dalam format Structure Query Language (SQL) yang berjumlah 28526 kata dasar. Data terakhir yang dibutuhkan dalam penelitian ini adalah data kata baku untuk normalisasi singkatan, data kata baku diperoleh dari penelitian (Aziz 2013) yang berjumlah 3719 kata baku, data kata baku disimpan di dalam basis data dalam format Structure Query Language (SQL).

\section{Tahapan Penelitian}

Penelitian ini terdiri atas beberapa tahapan, yaitu tahap pengumpulan data, tahap praproses, tahap pembagian data, tahap pemodelan klasifikasi, tahap pengujian, dan evaluasi hasil. Tahapan penelitian dapat dilihat pada Gambar 1.

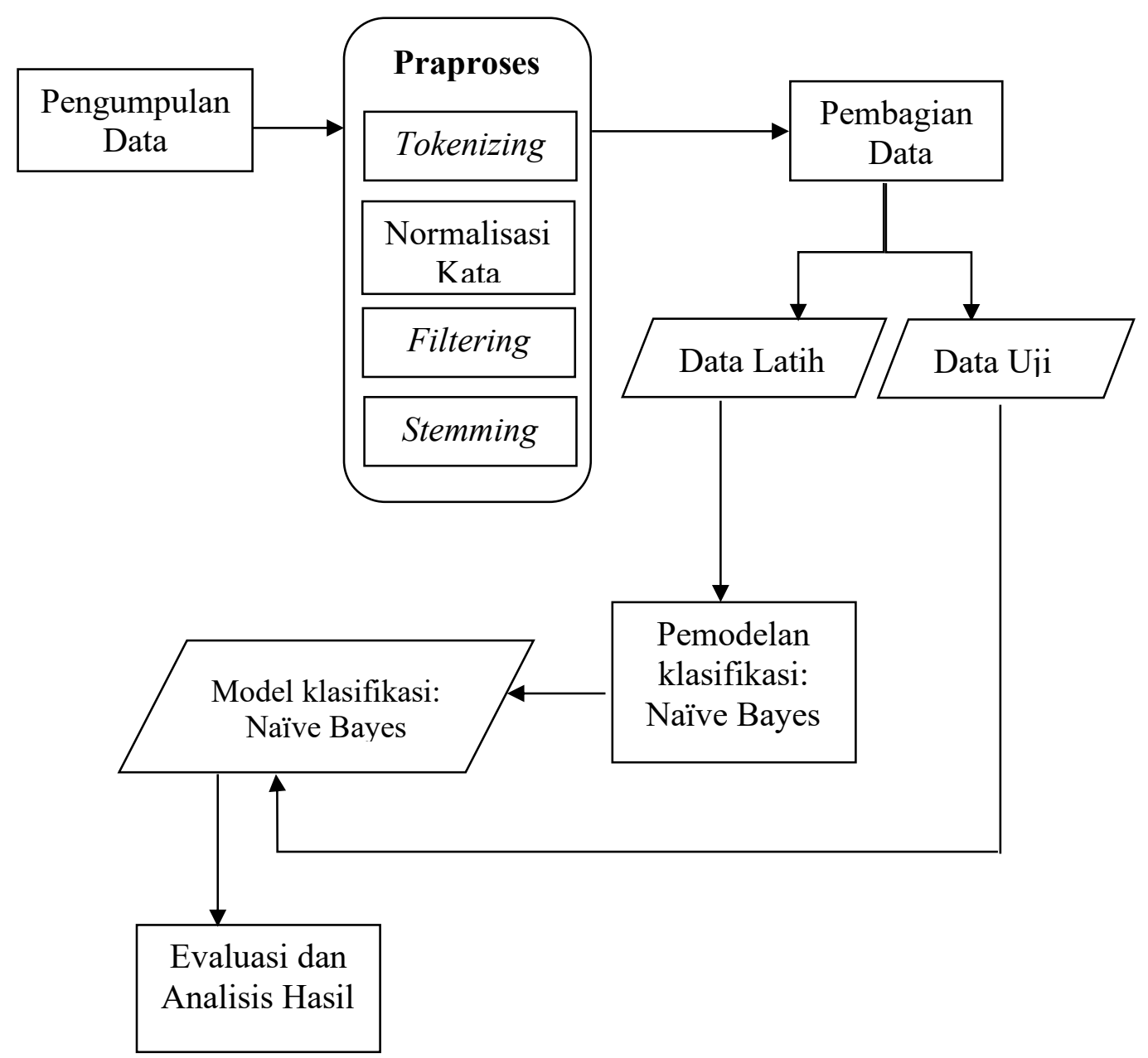

Gambar 1 Tahapan penelitian 


\section{Pengumpulan Data}

Tahap pengumpulan data dibutuhkan untuk mendapatkan isi tweet yang diambil dari Twitter, data diperoleh menggunakan Twitter API (Application Programming Interface). Data yang didapatkan masih berupa data campuran yaitu spam dan bukan spam. Data yang digunakan sebanyak 1000 tweet yang diambil dari 25 akun spammer dan 25 akun bukan spammer. Masing-masing akun diambil 20 tweet terbaru. Langkah yang dilakukan pada tahap pengumpulan data yaitu:

1 Mengumpulkan akun Twitter

2 Memberi label untuk akun spammer dan bukan spammer. Akun spammer dan akun bukan spammer ditentukan secara manual, akun yang dikategorikan sebagai akun spammer adalah akun yang mengirim tweet ke banyak pengguna Twitter dengan isi tweet yang sama atau hampir sama dalam waktu yang berdekatan.

3 Mengambil data tweet dari Twitter API dengan menggunakan package "twitteR" pada $\mathrm{R}$ dan menggunakan fungsi userTimeline.

4 Setiap data tweet diberi label sesuai dengan label akun, untuk akun spammer diberi label spam sedangkan untuk akun bukan spammer diberi label bukan spam.

\section{Praproses}

Setelah dilakukan tahap pengumpulan data berupa isi tweet pengguna Twitter, tahap selanjutnya adalah tahap praproses. Tahap praproses dibutuhkan karena data tweet yang tidak baku. Tahapan praproses dapat dilihat pada Gambar 2.

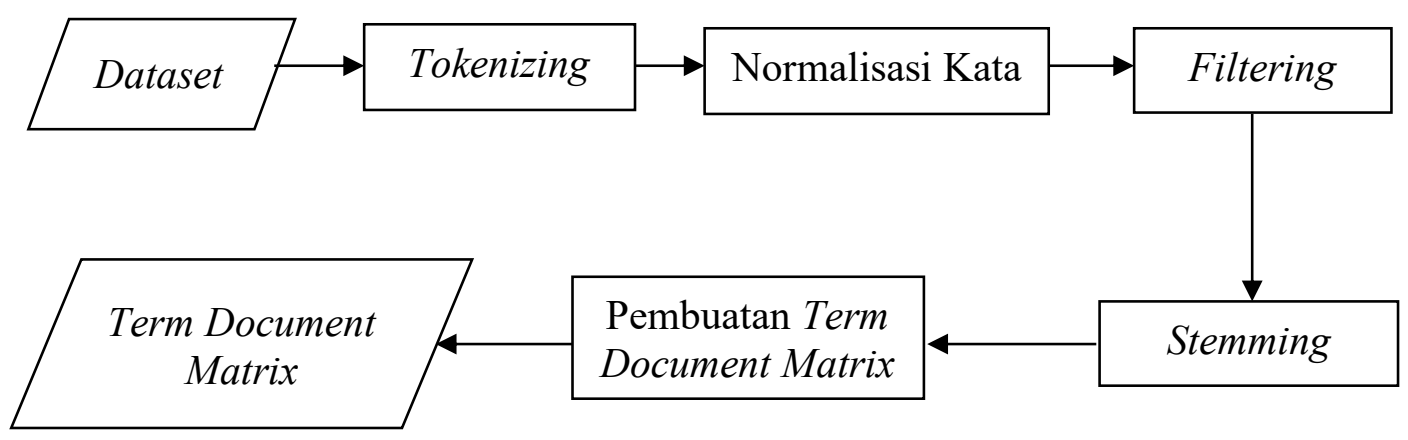

Gambar 10 Tahapan praproses data tweet.

- Tokenizing: Tahap pembuatan tokenisasi proses pertama yang dilakukan adalah membuat semua huruf pada tweet menjadi huruf kecil, proses selanjutnya adalah menghapus mention, URL, dan hashtag yang ada pada tweet, kemudian proses selanjutnya adalah penghapusan tanda baca dan angka.

- Normalisasi Kata: Normalisasi merupakan proses untuk penggantian kata yang tidak baku menjadi baku dan menghilangkan karakter berulang (Aziz 2013).

- Filtering: Pada tahap filtering, dilakukan penghapusan stopwords pada data tweet. Pengapusan stopwords dilakukan untuk menghilangkan kata- kata yang jika dihilangkan, data tweet masih memiliki makna. Penghapusan stopwords dilakukan pada tweet berbahasa Indonesia dan berbahasa Inggris. Penghapusan stopwords untuk bahasa indonesia menggunakan database stopwords Tala (2003) yang berjumlah 759 kata.

- Stemming: Proses stemming dilakukan menggunakan perangkat lunak Rstudio. Proses stemming dapat menggunakan package "tm" dan "snowball" yang tersedia pada R untuk beberapa bahasa. Namun, package tersebut belum mendukung untuk stemming teks berbahasa Indonesia. Sehingga dalam penelitian ini akan dilakukan stemming dengan menggunakan algoritme Nazief dan Adriani (1996).

- Pembuatan Term Document Matrix (TDM): Tahap selanjutnya adalah pembuatan term document matrix (TDM). TDM adalah matriks jumlah kemuculan suatu kata pada dokumen. Baris matriks menunjukkan kata yang ada pada data tweet, sedangkan kolom pada matriks 
menunjukkan tweet yang ada pada data tersebut.

\section{Pembagian Data}

Pada tahap pembagian data, data yang yang telah dilakukan praproses, kemudian data dibagi menjadi data latih dan data uji. Pembagian data uji dan data latih adalah 70 persen untuk data latih dan 30 persen untuk data uji.

\section{Pembuatan Model Klasifikasi Menggunakan Algoritme Naïve Bayes}

Klasifikasi adalah proses menemukan model atau fungsi yang menggambarkan dan membedakan kelas data model. Model ini digunakan untuk memprediksi kelas dari objek yang belum diketahui kelasnya. Proses klasifikasi dibagi menjadi 2 tahapan yaitu learning dan test, sebagian data yang telah diketahui kelas datanya (training set) digunakan untuk membentuk model dan pada tahap test, model yang sudah terbentuk kemudian diuji menggunakan sebagian data lainnya untuk mengetahui akurasi model tersebut (Han et al. 2012). Naïve Bayes merupakan metode yang digunakan untuk pemodelan klasifikasi, supervised learning merupakan pemodelan klasifikasi berbasis peluang, perhitungan peluang tersebut berdasarkan kaidah peluang Naïve Bayes dapat dilihat pada persamaan 1.

$$
\mathrm{P}(\mathrm{c} \mid \mathrm{d}) \propto \mathrm{P}(\mathrm{c}) \prod_{1 \leq \mathrm{k}<\mathrm{nd}} \mathrm{P}\left(\mathrm{t}_{\mathrm{k}} \mid \mathrm{c}\right)
$$

dengan parameter $\mathrm{P}(\mathrm{c})$ adalah peluang pada kelas $\mathrm{c}, \mathrm{P}\left(\mathrm{t}_{\mathrm{k}} \mid \mathrm{c}\right)$ adalah peluang token $t_{k}$ muncul pada $c$ dan $n d$ jumlah token unik. Pendugaan parameter $\hat{\mathrm{P}}(c)$ dan $\hat{\mathrm{P}}\left(\mathrm{t}_{\mathrm{k}} \mid \mathrm{c}\right)$ dapat dilihat pada persamaan 2 .

$$
\hat{\mathrm{P}}(\mathrm{c})=\frac{\mathrm{N}_{\mathrm{c}}}{\mathrm{N}}, \hat{\mathrm{P}}\left(\mathrm{t}_{\mathrm{k}} \mid \mathrm{c}\right)=\frac{\mathrm{T}_{\mathrm{ct}}}{\sum_{\mathrm{t} \in \mathrm{V}} \mathrm{T}_{\mathrm{ct}}}
$$

dengan $N_{c}$ adalah banyaknya peluang pada kelas c, $N$ adalah total dokumen, $\mathrm{T}_{\text {ct }}$ adalah banyaknya token $\mathrm{t}$ dalam dokumen data latih dari kelas c (Manning et al. 2009).

Tahap klasifikasi menggunakan algoritme Naïve Bayes. Setelah dilakukan tahap praproses, dari hasil praproses yang didapat, kata yang termasuk spam dan bukan spam, kemudian dihitung bobot untuk dapat diklasifikasikan menjadi spam dan bukan spam. Setelah dilakukan pemodelan klasifikasi menggunakan Naïve Bayes, tahap selanjutnya adalah dilakukan pengujian terhadap pemodelan menggunakan data uji yang telah tersedia, data tersebut juga dilakukan praproses seperti data latih.

\section{Evaluasi dan Analisis Hasil}

Proses evaluasi dapat dilakukan dengan cara membandingkan kelas aktual dari data uji dan kelas hasil prediksi dengan menggunakan confusion matrix.

\section{HASIL DAN PEMBAHASAN}

\section{Pengumpulan Data}

Pada tahap pengumpulan data, terdapat beberapa langkah. Berikut langkah- langkah pengumpulan data:

- Mengumpulkan akun Twitter. Langkah pertama dalam pengumpulan data adalah mengumpulkan akun Twitter, akun Twitter dipilih secara acak dari akun peneliti dan akun yang dipilih hanya akun yang bersifat public (bukan private).

- Memberi label untuk akun spammer dan bukan spammer. Setelah mengumpulkan akun Twitter, langkah selanjutnya adalah memberi label untuk akun spammer dan bukan spammer, pelabelan dilakukan secara manual, dengan cara melihat content. Jika, content 
termasuk dalam kategori spammer, akun akan diberi label sebagai spammer sedangkan jika content tidak termasuk kedalam kategori spammer, akun akan diberi label bukan spammer.

- Mengambil data tweet menggunakan fungsi userTimeline yang ada pada package "twitteR", Fungsi userTimeline, antaralain: text, favorite, favoritedCount, replyToSN, created, truncated, replyToSID, statusSource, screenname, retweetCount, isRetweet, retweeted, longitude, latitude, dan URL. Banyaknya atribut pada pengambilan data Twitter yang termasuk fungsi UserTimeline, pada penelitian ini atribut yang digunakan hanya atribut text. Data didapatkan menggunakan Twitter API (Application Programming Interface) kemudian data tersebut disimpan dalam format file .csv.

- Setiap data tweet diberi label sesuai dengan label akun. Setelah dilakukan pelabelan pada akun dan dilakukan pengambilan data tweet, langkah selanjutnya adalah pelabelan pada data tweet.

\section{Praproses}

Tahap praproses dibutuhkan karena data tweet yang tidak baku. Tahap praproses terbagi atas empat tahap yaitu, tokenizing, filtering, normalisasi kata, dan stemming. Tahap tokenisasi dilakukan menggunakan package "twitteR" dan package "tm" yang tersedia dalam R. Pada normalisasi kata dilakukan perbaikan dari kata tidak baku menjadi kata baku. Pada penelitian ini kode program diperoleh dari penelitian sebelumnya dilakukan oleh Khotimah (2014) dengan menggunakan kata baku yang ada pada penelitian Aziz (2013). Pada tahap filtering dilakukan penghapusan stopword pada data tweet. Penghapusan stopword dilakukan dengan menggunakan database stopword (Tala 2003) yang berjumlah 759 kata dan ditambah dengan stopword untuk menghilangkan term " $\mathrm{rt}$ ". Pada tahap filtering, kata yang termasuk dalam stopwords seperti ke, di, ada, dan rt akan dihapus. Dalam penelitian ini, stemming dilakukan menggunakan algoritme Nazief dan Adriani (1996). Kode program yang digunakan dalam penelitian ini untuk melakukan stemming berbahasa Indonesia menggunakan kode program yang diikuti dari penelitian Khotimah (2014).

Setelah dilakukan tahapan praproses sehingga didapat hasil token yang akan menjadi term. Term adalah token unik. Dapat dilihat perbedaan sebelum dan sesudah dilakukan praproses, kata sebelum dilakukan praproses tersebut direpresentasi dalam bentuk wordcloud yang dapat dilihat pada Gambar 3 dan hasil dari praproses tersebut direpresentasi dalam bentuk wordcloud yang dapat dilihat pada Gambar 4.

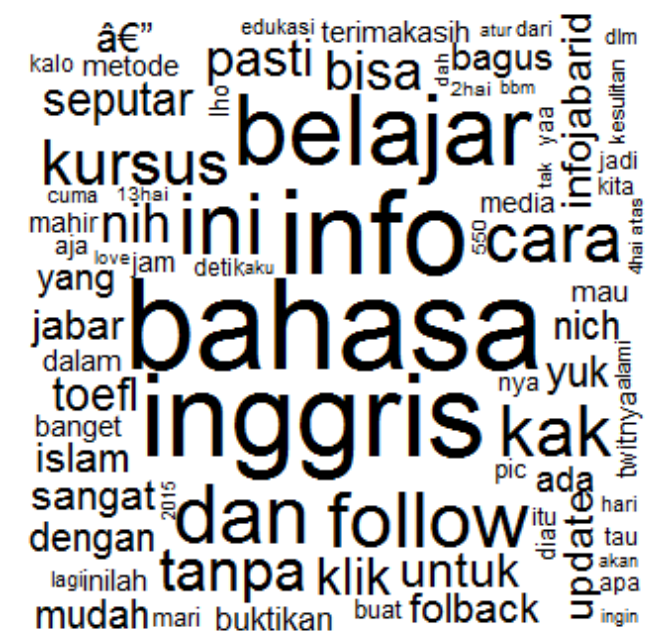

Gambar 3 Representasi wordcloud untuk term sebelum dilakukan praproses.

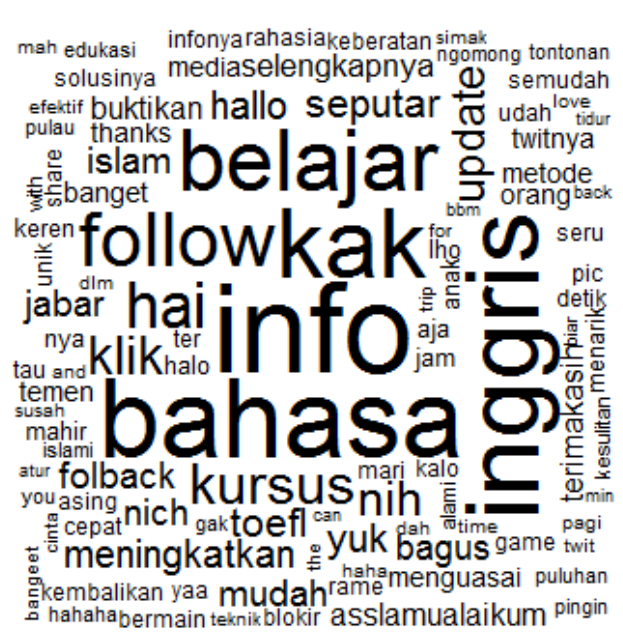

Gambar 4 Representasi wordcloud untuk term sesudah dilakukan praproses.

Dari Gambar 3 dapat dilihat bahwa term-term yang muncul sebelum dilakukan praproses masih mengandung angka dan tanda baca sedangkan Gambar 4 menunjukkan term-term yang 
muncul setelah dilakukan praproses, sudah tidak ada lagi angka dan tanda baca. Hasil dari praproses tersebut menghasilkan sebanyak 1648 terms dengan sparsity 100\% dan menyisakan 977 tweet, sparsity menggambarkan banyaknya angka nol dalam matriks. Pengurangan tweet yang sebelumnya terdapat 1000 data tweet dan menyisakan 977 tweet terjadi karena telah dilakukan tahapan praproses, karena terdapat tweet yang hanya berisi URL atau terdapat tweet yang hanya berisi angka saja. Setelah dilakukan praproses, matrix document-term dibuat untuk mengetahui frekuensi kemunculan term pada dokumen. Jumlah term yang muncul pada tweet spam sebanyak 197 terms dan jumlah term yang muncul pada tweet bukan spam sebanyak 1130 terms. Term-term yang muncul pada tweet spam dan tweet bukan spam dapat direpresentasikan dengan wordcloud. Hasil term pada kelas spam dapat dilihat pada Gambar 5 dan term pada kelas bukan spam dapat dilihat pada Gambar 6. Pada Gambar 5 dapat diketahui, term-term yang sering muncul pada kelas spam adalah bahasa, informasi, inggris dan pada Gambar 6 dapat diketahui term-term yang sering muncul pada kelas bukan spam memiliki frekuensi kemunculan yang hampir sama.

Banyaknya term yang dihasilkan membuat dimensi matrix menjadi besar, untuk memperkecil dimensi matrix dapat dilakukan dengan cara mereduksi terms yang memiliki tingkat kemunculan yang rendah dapat menggunakan fungsi removeSparseTerm() yang terapat pada package "tm". Nilai sparse adalah nilai numerik untuk sparsity maksimum yang dibolehkan dalam dokumen dengan rentang $0-1$. Sparsity $90 \%$ term yang memiliki paling sedikit $90 \%$ empty element, empty element adalah term yang muncul 0 kali dalam dokumen. adalah Hasil nilai sparse dan jumlah term yang dihasilkan dapat dilihat pada Tabel 1. Dari hasil nilai reduksi yang dapat dilihat pada Tabel 1, semakin kecil presentase term yang digunakan akan menghasilkan term yang semakin sedikit.

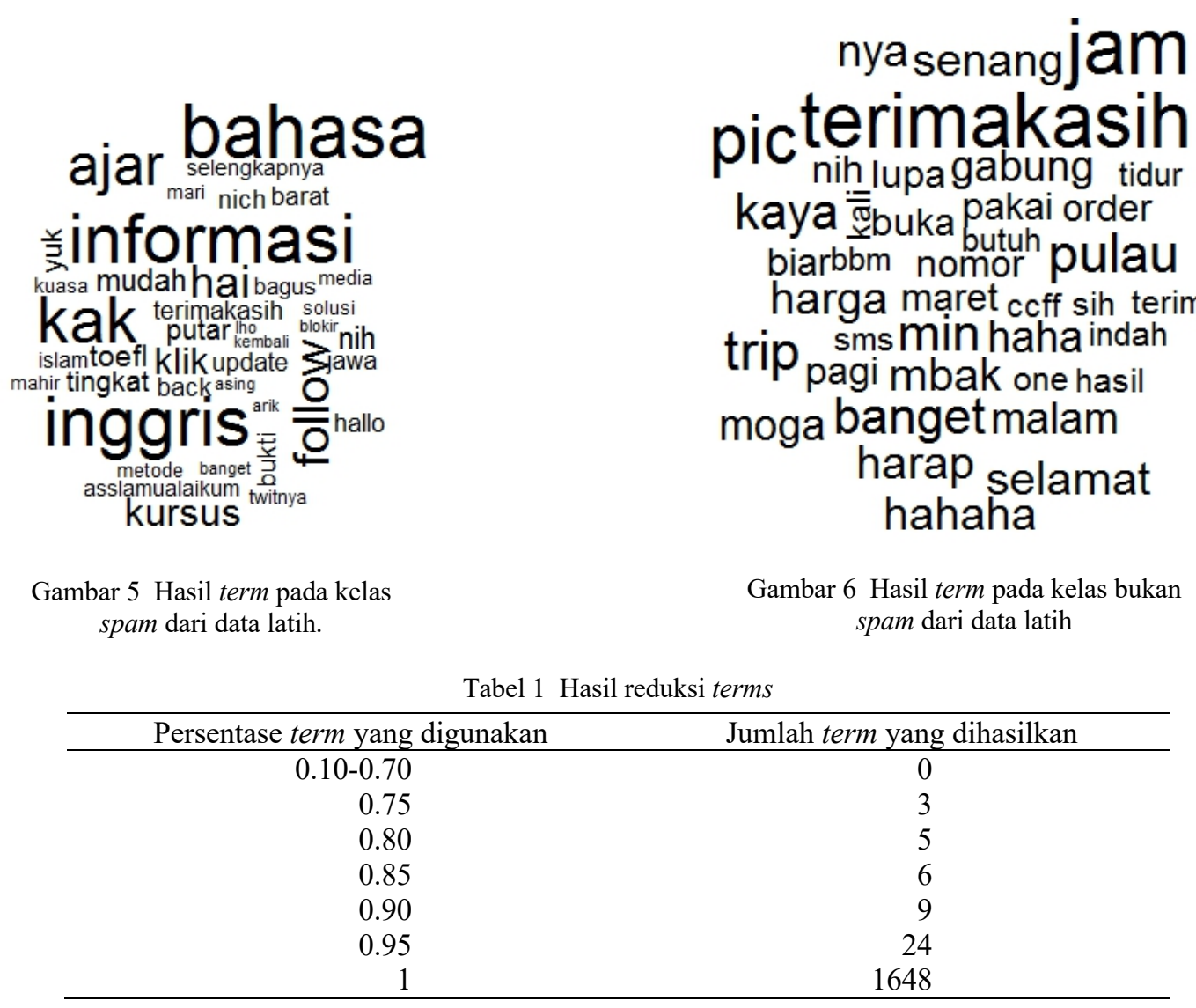

\section{Pembagian Data}

Pembagian data yang dilakukan adalah $70 \%$ untuk data latih dan $30 \%$ untuk data uji sehingga didapat 683 data latih dan 294 data uji. 


\section{Klasifikasi Menggunakan Algoritme Naïve Bayes}

Pada tahap klasifikasi, penelitian ini menggunakan algoritme Naiıve Bayes. sehingga dari hasil praproses, kata yang termasuk spam dan bukan spam, kemudian dihitung bobot per term untuk dapat diklasifikasikan menjadi spam dan bukan spam. Contoh hasil perhitungan peluang term dapat diklasifikasikan sebagai spam dan bukan spam dapat dilihat pada Tabel 2.

\begin{tabular}{lrr} 
Tabel 2 Contoh peluang term yang didapat menggunakan algoritme Näve Bayes \\
\hline \multicolumn{1}{c}{ Term } & Bukan Spam & \multicolumn{1}{c}{ Spam } \\
\hline Coba & 0.0029 & 0.0057 \\
Daftar & 0.0089 & 0 \\
Detik & 0.0059 & 0.0401 \\
Difolbek & 0 & 0.0143 \\
Disc & 0.0119 & 0.0000 \\
Edukasi & 0 & 0.0315 \\
Efektif & 0 & 0.0200 \\
Follow & 0.0059 & 0.3094 \\
Foto & 0.0149 & 0 \\
Gabung & 0.0209 & 0 \\
\hline
\end{tabular}

Setelah dilakukan klasifikasi data menggunakan Naïve Bayes, tahap selanjutnya adalah dilakukan pengujian terhadap hasil klasifikasi menggunakan data uji yang telah tersedia. Contoh hasil prediksi dapat dilihat pada Tabel 3.

Tabel 3 Contoh hasil prediksi

\begin{tabular}{llll}
\hline \multicolumn{1}{c}{ Teks } & \multicolumn{1}{c}{ Aktual } & \multicolumn{1}{c}{ Prediksi } & \multicolumn{1}{c}{ Hasil } \\
Prediksi
\end{tabular}

\section{Evaluasi dan Analisis Hasil}

Dari hasil nilai reduksi yang dapat dilihat pada Tabel 1, semakin kecil presentase term yang digunakan akan menghasilkan term yang semakin sedikit sehingga model tidak dapat memprediksi dengan lebih baik lagi dan menghasilkan akurasi yang kecil. Hasil akurasi dari hasil reduksi term dapat dilihat pada Tabel 4. Banyaknya duplikat tweet juga mempengaruhi tingginya akurasi.

Tabel 4 Hasil akurasi dari hasil reduksi term

\begin{tabular}{rrr}
\hline $\begin{array}{c}\text { Persentase term } \\
\text { yang digunakan }\end{array}$ & $\begin{array}{c}\text { Jumlah term } \\
\text { yang dihasilkan }\end{array}$ & Akurasi (\%) \\
\hline $0.10-0.70$ & 0 & - \\
0.75 & 3 & 85.71 \\
0.80 & 5 & 85.37 \\
0.85 & 6 & 93.87 \\
0.90 & 9 & 94.55 \\
0.95 & 24 & 94.55 \\
1 & 1648 & 95.57 \\
\hline
\end{tabular}

Perhitungan evaluasi dengan cara membandingkan kelas aktual dari data uji dan kelas hasil prediksi dengan menggunakan confusion matrix. Confusion matrix dapat dilihat pada Tabel 5. 
Tabel 5. Confusion matrix

\begin{tabular}{lrr}
\hline \multirow{2}{*}{ Prediksi } & \multicolumn{2}{c}{ Aktual } \\
\cline { 2 - 3 } & Bukan Spam & Spam \\
\hline Bukan Spam & 139 & 9 \\
Spam & 4 & 142 \\
\hline
\end{tabular}

Dari confusion matrix pada Tabel 5, dapat diketahui bahwa 142 data dengan kelas aktual spam dan benar diprediksi sebagai spam. Sementara data aktual spam yang salah diprediksi sebagai bukan spam sebanyak 9 data. Untuk data dengan kelas aktualnya bukan spam tetapi diprediksi sebagai spam sebanyak 4 data, sementara data yang benar sebagai bukan spam dan diprediksi sebagai bukan spam ada sebanyak 139 data. Tweet yang salah prediksi dapat dilihat pada Tabel 6. Akurasi hasil klasifikasi yang didapat adalah $95.57 \%$.

Tabel 6. Data tweet yang salah prediksi

\begin{tabular}{|c|c|c|c|}
\hline No. & Text & Aktual & Prediksi \\
\hline 1 & wajib baca tips alami mutih kulit tubuh cepat & Spam & Bukan Spam \\
\hline 2 & sebab hilang komedo alami & Spam & Bukan Spam \\
\hline 3 & rahasia kecil paha betis & Spam & Bukan Spam \\
\hline 4 & hilang ketombe rambut alami & Spam & Bukan Spam \\
\hline 5 & tips atas rambut rontok alami & Spam & Bukan Spam \\
\hline 6 & tips atas rambut rontok alami & Spam & Bukan Spam \\
\hline 7 & urun berat badan minggu alami & Spam & Bukan Spam \\
\hline 8 & halo kejar toefl score atas baca & Spam & Bukan Spam \\
\hline 9 & halo kejar toefl score atas baca & Spam & Bukan Spam \\
\hline 10 & tips rawat rambut kering alami & Spam & Bukan Spam \\
\hline 11 & malas $\mathrm{kl}$ tugas isi bahasa inggris video ppt text book & Bukan Spam & Spam \\
\hline 12 & hallo sajadah alas kasur ready stok nih & Bukan Spam & Spam \\
\hline 13 & $\begin{array}{l}\text { kak madam listrik kp nanggoh ds cimande c caringin } \\
\text { kab bogor ya penyebabnya terimakasih }\end{array}$ & Bukan Spam & Spam \\
\hline
\end{tabular}

Dari Tabel 6, diketahui bahwa ada 13 tweet yang diprediksi salah, yaitu 10 data yang kelas sebenarnya adalah spam tetapi diprediksi sebagai bukan spam dan 3 data yang kelas sebenarnya bukan spam tetapi diprediksi sebagai spam, hal tersebut disebabkan banyaknya kata-kata pada tweet bukan spam muncul pada korpus data spam, sehingga tweet tersebut diprediksi sebagai spam dan sebaliknya banyak kata-kata pada tweet spam yang diindikasi sebagai bukan spam, sehingga tweet tersebut diprediksi sebagai bukan spam. Hal ini salah satunya dapat dipengaruhi oleh content spam yang didominasi oleh tweet promosi

\section{SIMPULAN}

Penelitian ini menggunakan algoritme Naïve Bayes untuk mengklasifikasikan spam dan bukan spam dengan menggunakan data Twitter, algoritme Naïve Bayes dapat dikatakan baik untuk klasifikasi spam dan bukan spam pada Twitter karena memiliki akurasi yang tinggi sebesar $95.57 \%$, salah satu faktor yang mempengaruhi tingginya akurasi adalah karena penelitian ini mengabaikan duplikat tweet sehingga setiap tweet yang memiliki isi yang sama tetap dianggap sebagai tweet yang berbeda.

Dari penelitian ini juga dapat diketahui term-term yang termasuk spam dan bukan spam, term-term yang sering muncul pada kelas spam adalah bahasa, follow, inggris, sehingga dapat diketahui pada penelitian ini tweet spam didominasi dengan konten tweet promosi bahasa Inggris. 


\section{DAFTAR PUSTAKA}

Adriani M, Asian J, Nazief B, Tahaghoghi SM, Wiliams HE. 1996. Stemming indonesian: a confix-stripping approach. ACM Transactions on Asian Language Information Processing. 6(4):1-33

Aziz ATA. 2013. Sistem pengklasifikasian entitas pada pesan twitter menggunakan ekspresi reguler dan Naïve Bayes [skripsi]. Bogor (ID): Institut Pertanian Bogor.

Chakraborty M, Pal S, Pramanik R, Chowdary CR. 2016. Recent developments in social spam detection and combating techniques: A survey. Information Processing \& Management. 52(6):1053-1073.

Gupta H, Jamal MS, Madisetty S and Desarkar MS. 2018. A framework for real-time spam detection in Twitter. Di dalam: 2018 10th International Conference on Communication Systems \& Networks (COMSNETS); Bengaluru, 2018 Jan 3-7. Bengaluru (IN). hlm: 380383.

Han J, Kamber M, and Pei J. 2012. Data Mining: Concepts and Techniques. 3rd. Massachusetts (US): Morgan Kaufmann.

Kemenkominfo, Kementerian Komunikasi Informatika. 2013. Kominfo:pengguna internet di Indonesia 63 juta orang [internet]. [Diunduh 2015 Jun 27]; http://kominfo.go.id/ index.php/content/detail/3415/\%20Kominfo+:+Pengguna+Internet + di + Indonesia $+63+\mathrm{J}$ uta+Orang/0/berita satker

Khotimah H. 2014. Pemodelan hybrid tourism recommendation menggunakan hidden markov model dan text mining berbasis data sosial media [tesis]. Bogor (ID): Institut Pertanian Bogor.

Makhtidi K. 2012. Sistem SMS spam detector untuk sms Berbahasa Indonesia pada smartphone android [skripsi]. Bogor (ID): Institut Pertanian Bogor.

Manning CD, Raghavan P, Schütze H. 2009. An Introduction to Information Retrieval. Cambridge (UK): Cambridge University press.

McCord M and Chuah M. 2011. Spam detection on twitter using traditional classifier. Di dalam: M Jose, editor. Autonomic and Trusted Computing: 8th International Conference; Banff, 2011 Sep 2-4. San Francisco(US): Springer. hlm: 175-186.

Metsis V, Androutsopolous I, Paliouras G. 2006. Spam Filtering With Naïve Bayes -Which Naïve Bayes?. Di dalam: Third Conference on Email and Anti-Spam; Mountain View, 2006 Jul 27-28. California(US).

Palupiningsih P. 2011. Sistem pengklasifikasian entitas pada pesan Twitter menggunakan ekspresi regular dan Naïve Bayes [tesis]. Bogor (ID): Institut Pertanian Bogor.

Tala FZ. 2003. A study of stemming effects on information retrieval in Bahasa Indonesia [tesis]. Amsterdam (NL): Universiteit van Amsterdam.

Wang A H. 2012. Machine Learning for the Detection of Spam in Twitter Networks. Di dalam: Obaidat MS, Tsihrintzis GA, Filipe J. (eds) e-Business and Telecommunications. ICETE 2010; Heidelberg, 2010 Jul 26-28. Berlin (DE): Springer. hlm: 319-333. 